\title{
ERITREA-ETHIOPIA ARBITRATION:
}

\section{A 'Cure' Based on Neither Diagnosis nor Prognosis}

Seyoum Yohannes Tesfay*

\begin{abstract}
The Eritrea-Ethiopia peace process remains stalled a decade after the arbitral award by the Boundary Commission and several years after awards by the Claims Commission. This article assesses why arbitration by the two commissions did not produce the desired outcome. To this end, the author analyzes primary and secondary sources and argues that arbitration was not the right method of conflict resolution. Mayer's multi-dimensional approach to conflict and conflict resolution informs the discussion that the conflict between the two countries has cognitive, emotional and behavioral dimensions. It is argued that arbitration as a settlement of dispute by purely legal means is ineffective to adequately address the multiple dimensions of the conflict. The author underscores that such conflicts can only be resolved by using a combination of different interventions. Specifically, while arbitration may be appropriate to deal with some essentially resource related matters, the resolution of emotional and cognitive dimensions of this conflict call for a multi-track approach in which different segments of the people from the two countries can play critical roles.
\end{abstract}

\section{Key words}

Conflict resolution, arbitration, border conflict, boundary commission, claims commission, multi-track, peace, Eritrea, Ethiopia.

DOI http://dx.doi.org/10.4314/mlr.v6i2.1

\section{Introduction}

Ethiopia and Eritrea 'sought' to resolve all aspects of their conflict by arbitration. To this end, they established Boundary and Claims Commissions. Although the two Commissions have given awards in respect of all the matters submitted to them, none of these awards have been implemented. What is worse, the two countries still remain on a war footing. The author contends that this is in part attributable to the ineffectiveness of arbitration as the sole mechanism to resolve the conflict.

\footnotetext{
* Assistant Professor, Addis Ababa University School of Law; also teaches on part-time basis at the Institute for Peace and Security Studies. The author's deepest gratitude goes to all those who contributed to this work in a variety of ways. Email: dayaseyoum@yahoo.com
} 
The first section of the article highlights the meaning and causes of conflict and sheds some light on interstate conflict. Section 2 introduces the states at conflict and the relationship between the leaderships of the two countries. Particularly, the multiple underlying causes of the conflict are discussed. In Section 3, the claims litigated before the two arbitral tribunals and the awards given are presented in brief. The fourth section demonstrates the mismatch between arbitration and the Eritrea-Ethiopia conflict. The last section, examines the parallels between the conflict resolution scheme and the dimensions of conflict. Then, a few observations are stated as to how resolution of the conflict between the two countries should be attempted.

As regards methodology, a mix of qualitative and quantitative methods has been utilized. It should, however, be noted from the outset that participants in the field study do not necessarily represent the populations of the two countries. The objective of this article is not to generalize about the entire populations of the two countries directly from the sample. The aim of the sample is rather limited to shedding some light on the views and feelings of certain influential segments of the societies in the countries at conflict and those that were particularly affected by the conflict. This being the objective, the participants were for the most part people living close to the border, refugees from Eritrea, Ethiopian deportees from Eritrea, persons who were considered opinion makers and others.

\section{Conflicts in General and Interstate Conflict: An Overview}

\subsection{Conflict: Meaning and Causes}

Conflict has different meanings in different contexts. For some it refers to 'behavior' or 'action'. For instance, there is a conflict when a trade union goes on 'strike' or when two states are at 'war'. According to Wallensteen if these events merely involved 'actions', conflict would be over when the behavior or action ends, say when war stops. He notes that conflict is rather a 'social situation in which a minimum of two actors (parties) strive to acquire at the same moment in time an available set of scarce resources'. ${ }^{1}$ In a bid to explain his definition he writes, one needs to note elements like 'strive' and 'scarce resources'. The word strive refers to the parties doing 'something' however minimal to acquire the resource. So strive includes anything, 'war' being its highest form. He further states that the notion of 'available set of scarce resources' should be interpreted broadly to include non-material/non-economic resources. Accordingly, the term 'resources' covers all kinds of positions that

\footnotetext{
${ }^{1}$ Peter Wallensteen (2007), Understanding Conflict Resolution (London and Thousand Oaks: SAGE Publications Limited, $2^{\text {nd }}$ ed), p. 15.
} 
are of interest to an actor. So it can, inter alia, include territory, position of power, acceptance of responsibility for destructive actions, psychological needs like retribution and other intangible values. ${ }^{2}$

Johan Galtung proposes an influential model regarding how conflict takes place. According to this model, 'conflict' can be viewed as a triangle with attitude (A), behavior (B) and contradiction(C) at its vertices. "Attitude" refers to disposition towards an adversary and has two elements, the cognitive and emotive. The cognitive element refers to the mental image one holds about the enemy while the emotive element relates to the affect or emotions, the feelings one has towards an adversary". "B", the behavioral dimension refers to what parties do such as gestures signifying cooperation or/and coercion. In violent conflicts the behavior could be violent attack. That will be war if it involves the coordinated use of violent force in combination with other instruments according to Clausewitz. ${ }^{5}$ Finally, "contradiction" in this model refers to the underlying conflict situation including actual and perceived 'incompatibility of goals' between the parties to the conflict. These three dimensions taken together make the conflict system wherein each reinforces the others. ${ }^{6}$ Conflict is a dynamic phenomenon. One actor is reacting to what another actor is doing, that further leads to yet another action to the extent that it may become difficult to decipher who is more responsible. ${ }^{7}$

\subsection{Interstate Conflict: The Different Levels of Analysis}

Many have grappled with the causes of interstate conflict and other forms of state behavior. Particularly, the causes of war have been analyzed in different ways. Waltz's 'level-of-analysis framework' can be a useful tool in making sense of the varied understanding of causes of war and other state behavior. His level-of-analysis framework divides the causes of war in terms of whether they are located at the level of the individual, the nation-state or international system. ${ }^{8}$

${ }^{2}$ Ibid.

${ }^{3}$ Johan Galtung cited in Kenneth Fox (2007), "What Private Mediators Can Learn from the Peace- Builders", Cardozo Journal of Conflict Resolution, Vol 7, p. 245.

${ }^{4}$ Oliver Ramsbotham, Tom Woodhouse and Hugh Miall (2005), Contemporary Conflict Resolution (Cambridge and Malden : Polity Press), p. 10.

5 Jack Levy (2007), "International Sources of Interstate and Intrastate War", in Chester Crocker, Fen Hampson and Pamela Aall (edds) Leashing the Dogs of War

(Washington: US Institute of Peace Press), p. 20.

${ }^{6}$ Galtung, cited at note 3 above.

${ }^{7}$ Wallensteen, supra note 1, p. 32.

${ }^{8}$ Levy, supra note 5, p. 21. 
The first, the individual level, focuses primarily on human nature and inclinations towards aggression. In this thinking, wars are ultimately clashes not of armies, laws, or even cultures but of masses of individuals each of whom is a distinct personality and whose behavior while affected by the command of the superior officer, laws and symbols, is also affected by individual hereditary as well as individual experiences. ${ }^{9}$ Hence, the personalities, belief systems, psychological process of individuals, particularly, leaders such as heads of state are subject of emphasis at this level of analysis. The implication of the individual level of analysis could be that, if a different person had been the leader, the state would have behaved differently; say would not have gone to war. ${ }^{10}$ The second, the national level, considers wider factors and settings as points of focus, such as the structure of the political system, policy making process, the role of public opinion, interest groups, ethnicity and nationalism, political culture and ideology. ${ }^{11}$ The third level, also called the system-level, includes variables like the structure of the international system, number of major powers in the system, norms influencing their behavior, patterns of international trade and military alliance and other factors that constitute the external environment to states. ${ }^{12}$

At this juncture one notes that no single level of analysis provides a complete explanation for the causes of war given the complexity of international politics. Hence, many theories of war combine causal variables from different levels of analysis, i.e., the individual, nation-state, and systems level. ${ }^{13}$ Another point to be noted in this connection is that showing or explaining why a state or a leader wants war is not enough. Since interstate war involves violence between two political organizations, a theory of war must explain why both states fight. For this reason, a complete analysis will not be achieved solely at 'individual' or state level. Analysis of a war at the system level becomes inevitable where more than one country will have to be studied. ${ }^{14}$ In this article, the focus of analysis will be at the nation-state level though the other two levels have undeniably their own contributions.

According to Mayer, nation-state level conflicts could be viewed as occurring along three dimensions; these are cognitive (perception), emotional

\footnotetext{
${ }^{9}$ Quincy Wright (1964), A Study of War, (2 ${ }^{\text {nd }}$ Abridged ed.), (Chicago: University of Chicago Press), p. 112.

${ }^{10}$ Levy, supra note 5, pp. 20-21.

${ }^{11}$ Ibid.

12 Ibid.

${ }^{13}$ Ibid., p. 22

${ }^{14}$ Ibid., p. 23.
} 
(feeling/identity) and behavioral (action) dimensions. ${ }^{15}$ These are essentially the elements that make two of the three vertices of Galtung's triangle stated above. The cognitive and emotional dimensions constitute the 'attitude' vertex while the behavioral dimension in Mayer's analysis is exactly the same as the 'behavior' vertex in Galtung's triangle. Mayor's three dimensions will inform the analysis of the Eritrea-Ethiopia conflict where necessary in the course of the discussion in the following sections.

\section{An Overview of the Eritrea-Ethiopia Conflict: the Parties and Underlying Causes}

The 1998-2000 'border' war represents the highest point in the current EritreaEthiopia conflict. It also provided the setting for a multitude of violations of humanitarian and human rights laws that were brought before the EritreaEthiopia Claims Commission. But did Ethiopia and Eritrea really fight over the disputed territory which some called 'inconsequential piece of real estate' owing to the small size and absence of known resources? How is it possible for two formerly 'friendly' governments to turn into deadly adversaries in a matter of weeks, willing to sacrifice tens of thousands of their people on the battlefields? Why is it that we have simmering tensions between the two countries a decade after the ceasefire and an arbitral award on the 'disputed border' has been given? Why did the awards by the Claims Commission on the consequences of the war fail to be implemented? Even more so, why are these arbitral awards used as propaganda tools for what one may call a 'cold war'?

An international dispute is not an isolated event. It has a past and presumably some sort of a future. ${ }^{16}$ It cannot be understood independently of its historical context. According to Mayer, "the history of the people who are participants in a conflict, of the system in which the conflict is occurring and of the issues themselves has a powerful influence on the course of the conflict". ${ }^{17}$ This observation is particularly correct regarding the conflict between Eritrea and Ethiopia. Hence, a proper understanding of the conflict and the way forward presupposes having an in-depth knowledge of the two countries, their peoples as well as the leaderships at conflict. Unfortunately, it is impossible to do justice to such broad and complex subjects in an article like this. Therefore, only a cursory look at the relationship between the two countries, their people and the political leadership will be attempted.

\footnotetext{
${ }^{15}$ Bernard Mayer (2000), The Dynamics of Conflict Resolution: A Practitioner's Guide (San Francisco: Jossey-Bass), p. 4.

${ }^{16}$ Jacob Bercovittch (1996), Resolving International Conflicts: The Theory and Practice of Mediation (Boulder: Lynne Reinner Publishers), p.16.

${ }^{17}$ Mayer, supra note 15, p. 13.
} 


\subsection{The Relationship between the Two People and Countries}

Ethiopia and Eritrea occupy most of the Horn of Africa. Eritrea has a land and sea area of about 117,600 square kilometers and a population of about 6 million. Ethiopia is relatively a big country, almost ten times the size of Eritrea and a population of about 93 million. ${ }^{18}$ Ethiopia lost the entire coastline along the Red Sea upon the independence of Eritrea in 1993. Thus, Ethiopia is landlocked whereas Eritrea has a coastline of 1200 kilometers. ${ }^{19}$

Since some two thousand years back, most of today's Tigray and much of Eritrea saw intensive intercommunication of various peoples. The intermingling of 'humans, animals, plants cultures and ideas across the Red Sea produced a distinct civilization that can be deemed Afro-Asiatic'. Its heartland was Axum, the antecedent of the modern Ethiopian state. ${ }^{20}$ Owing to this, there are primordial ties between various ethnic groups living in both countries. For instance, four of the nine languages spoken in Eritrea are widely spoken in Ethiopia. ${ }^{21}$

This is particularly clear when it comes to the Tigrigna-speaking community straddling the border between the two countries. The Tigrayans and Eritreans of the southern highlands (kebesa) spoke the same language, Tigrigna. They use the same script, and belonged to the same political realm and Orthodox Church with its Geez liturgy. Moreover, these two people shared the same agrarian culture and social hierarchy. ${ }^{22}$ Common people on both sides of the Mereb River admit the existence of this close cultural, ethnic and linguistic ties although individuals from different walks of life accord slightly different weight and meaning to those relationships. ${ }^{23}$

While the above commonalities inform the historical and cultural similarities of the peoples of both countries to this day, the two countries have a period of

${ }^{18}$ CIA, The World Factbook: available at <https://www.cia.gov/library/publications/the-world-factbook/geos/html>, accessed on August 3, 2012.

${ }^{19}$ Berhane Woldegabriel (2006), 'A War for National Unity' in Lenco Leeta (ed), The Search for Peace: The Conflict Between Ethiopia and Eritrea, July 2006, available at: <www.fafo.no/pub/rapp/20014/20014.pdf>, accessed on May 29, 2012.

${ }^{20}$ Gebru Tareke (2009), The Ethiopian Revolution: War in the Horn of Africa, (New Haven: Yale University Press), p. 55. See also Alemseged Abbay (1998), Identity Jilted, or, Re-Imagining Identity? The divergent paths of the Eritrean and Tigrayan Nationalist Struggles, (Lawrenceville: Red Sea Press).

${ }^{21}$ Berhane, supra note 19, p. 34.

${ }^{22}$ Gebru, supra note 20, p.55.

${ }^{23}$ Alemseged, supra note 20, p.160. 
separate history, which the political leadership of both have played up or played down depending on their political aspirations. ${ }^{24}$ Here it should be noted that some Eritrean sources totally disagree with any assertion that Eritrea was ever part of Ethiopia. Although they agree most parts of Eritrea were part and parcel of the Axumite kingdom, they contend that the Ethiopian state cannot and should not be deemed to be the inheritor of the Axumite kingdom. ${ }^{25}$ In the more recent past, while Ethiopia remained independent, Eritrea was colonized by Italy from 1891 to $1941 .^{26}$ Subsequently, Eritrea was under British rule from 1941 to $1952 .{ }^{27}$

In December 1950 the United Nations General Assembly by Resolution 390 $\mathrm{A}(\mathrm{V})$ decided that Eritrea be grated autonomous federal status under the sovereignty of the Ethiopian Crown not later than 15 September 1952. Many Eritreans question the legitimacy of this decision. Ruth, an Eritrean intellectual for instance, contends that Ethiopia exploited traditional Eritrean societal cleavages and manipulated the nascent party politics prevalent at the time in Eritrea. ${ }^{28}$ The societal cleavages that she talks about refer to highland-lowland, Christian-Muslim dichotomy that is raised by several authors in relation to this. Particularly, a considerable segment of the Muslim community opposed the Federal arrangement. ${ }^{29}$ Whether Ruth's interpretations are correct or not it is incontestable that the people of Eritrea did not vote on this issue of federation with Ethiopia. Both Eritrean and Ethiopian sources confirm this. ${ }^{30}$

${ }^{24}$ Tekeste Negash (1997), Eritrea and Ethiopia:The Federal Experience, (New Brunswick: Transaction Publishers), p. 13.

${ }^{25}$ Othman Saleh Sabby, The History of Eritrea, available at:

<www.eritrios.net/the_history_of_eritrea.htm>, accessed on August 3, 2012. The author who was one of the founders of the Eritrean Liberation Front and the official spokesperson for the external mission of the Popular Liberation Forces of Eritrea contends that Eritrea is part of the Arab homeland, which the sea could not separate from the Arab Peninsula.

${ }^{26}$ Tekeste, supra note 24, p. 13.

27 Ibid, p. 18.

${ }^{28}$ Ruth Iyob (1995), The Eritrean Struggle for Independence: Domination, Resistance, Nationalism (New York: Cambridge University Press), p. 86.

${ }^{29}$ Tekeste Negash (2007), 'The Dilemma of Eritrean Identity and Its Future Trajectories' A Paper read at the $4{ }^{\text {th }}$ Congress of the Association of African Historians, May 2007, read generally, available at:

<http://asmarino.com/en/articles/242-the-dilemma-of-eritrean-identity-and-its-futuretrajectories >, accessed on June 14, 20012.

${ }^{30}$ Bereket Habte Selassie (1989), Eritrea and the United Nations (Lawrenceville: Red Sea Press), p.27, See also Bahru Zewde (2006), 'Eritrea and Ethiopia: In Quest of a Culture of Peace and Dialogue' in Lenco Leeta (ed.), supra note 19, p.17. 
Once federation was attained, the federal arrangement that aimed at satisfying unionist and pro-independence segments of the Eritrean society was found unsatisfactory to both sides. According to Bahru the Unionists that had the upper hand in the newly constituted Eritrean Government systematically eroded the federal arrangement excelling in zeal the Government in Addis Ababa. ${ }^{31}$ Bahru further writes that the Emperor welcomed and even encouraged these developments because the federal arrangement was an anomaly given the centralized, autocratic, feudal system in Ethiopia. ${ }^{32}$ Finally, in 1962 the federal arrangement was abolished when the Eritrean Parliament voted for unitary system, which according to many Eritrean sources resulted from the pressure and intrigue exerted by Emperor Haileselassie. ${ }^{33}$

This resulted in liberation struggle by several Eritrean groups, which led to 30 years of civil war or 'liberation war' according to many Eritreans. This war brought untold misery to the people of both countries. ${ }^{34}$ In April 1993, Eritrea gained de jure independence following a UN sponsored referendum held on April 23/24. Ethiopia extended recognition to Eritrea's sovereignty and independence on April 29, 1993 just two days after the results of the referendum were announced and three weeks before the independence of Eritrea was formally declared. ${ }^{35}$

\subsection{The Relationship between the Leaderships of the Two Countries}

The parties in power in both countries, the Tigray People's Liberation Front, TPLF, now subsumed into the Ethiopian People's Revolutionary Democratic Front, EPRDF, and the Eritrean People's Liberation Front, EPLF, now renamed People's Front for Democracy and Justice, PFDJ, were guerrilla organizations fighting in close cooperation for nearly 17 years. As guerrilla movements, their major power base was the same ethnic group, Tigray/Tigriya found in both

${ }^{31}$ Ibid.

${ }^{32}$ Ibid.

${ }^{33}$ Bereket Habte Sellassie, supra note 30, p. 43.

${ }^{34}$ Ruth Iyob (1995), supra note 28, p.96.

${ }^{35}$ Ruth Eyob (2000), "The Ethiopian-Eritrean Conflict, Diasporic vs. Hegemonic States in the Horn of Africa", The Journal of Modern African Studies, Vol. 38, No 4, p. 670, See also Eritrea-Ethiopia Boundary Commission, Decision Regarding Delimitation of the Border between Eritrea and Ethiopia, Decision of 13 April 2002, p. 105, available at: 〈www.untreaty.un.org/cod/riaa/cases/vol_XXV/83-195.pdf〉, accessed on August 3, 2012. 
countries. What is more, after the two organizations came to power, the party now in power in Ethiopia facilitated and endorsed Eritrea's independence. ${ }^{36}$

Notwithstanding the above facts, those who have studied the two organizations closely have maintained that the two parties had disputes on a range of ideological, military as well as national questions. Aregawi Berhe, one of the founders of the TPLF and member of the leadership until 1985, confirms the above. According to him, the TPLF-EPLF relationship was amorphous from the very beginning. In his view, it was by and large the pressure from the common enemy that propelled the relationship to work to the extent it did. ${ }^{37}$

When the two fronts were fighting the Dergue, the most enduring disagreements between the two pertained to differing points of view on the nature of the Soviet Union, the question of nationality, and military strategy to be applied for combating the Dergue. ${ }^{38}$ Regarding the question of nationality, for instance, the major point of difference was that the TPLF insisted officially that if post-independence Eritrea was to be democratic it would have to recognize and respect the rights of nations and nationalities in Eritrea to selfdetermination including and up to secession. ${ }^{39}$ As Eritrea has nine ethnic groups, unlike nearly homogenous Tigray, this stand of the TPLF did not suit the vision EPLF had for Eritrea. ${ }^{40}$

In 1985, these tense circumstances led to the withdrawal of TPLF's last contingent from the Eritrean trenches in Sahel where they had been deployed to help the EPLF. Months later, the EPLF retaliated by taking a series of measures that angered not only the TPLF but many Tigrayans from different walks of life. The measures included blocking the TPLF from using the only route to the Sudan from where the food aid to the population suffering from one of the worst famines would be obtained, and closing the 'Dimtsi Woyane', a TPLF radio operating from EPLF territory in Sahel. These measures led to a complete breakdown of relationship between the two and the TPLF began openly supporting various splinter groups of ELF against EPLF. ${ }^{41}$ The TPLF and EPLF

\footnotetext{
${ }^{36}$ Kjetil Tronvoll (2009), War and Politics of Identity in Ethiopia (Chippenham: Boydell and Brewer Inc.), p. 46.

37 Aregawi Berhe (2009), A Political History of the Tigray People's Liberation Front (1997-1991) (Los Angeles: Tsehai Publishing and Distributors), p.210.

${ }^{38}$ Ibid, p. 218.

39 John Young (1996), 'The Tigrayan and Eritrean Eritrean Liberation Fronts: A History of Tensions and Pragmatism', The Journal of Modern African Studies 34(1), (105) p. 112.

40 Ibid.

${ }^{41}$ Aregawi Berhe, supra note 37, p. 220.
} 
resumed relations only after April 1988 when they agreed to put aside their propaganda and attacks against each other, and to fight the Dergue together. ${ }^{42}$

\subsection{The 1998-2000 War: The Underlying Causes}

As indicated earlier, conflict may be viewed as occurring along cognitive (perception), emotional (feeling), and behavioral (action) dimensions. ${ }^{43}$ As Mayer notes "conflict among groups clearly has cognitive, affective, as well as behavioral dimensions" even if "we might better use terms like culture, ethos, public opinion or popular beliefs to signify the greater complexity and different nature of these dimensions in social systems". ${ }^{44}$ This three-dimensional perspective, as stated above, essentially conforms to Galtung's triangle of conflict. This perspective can explain the Eritrea-Ethiopia conflict.

\subsubsection{The behavioral dimension of the conflict}

The behavioral or action dimension of conflict, consists of actions that people take to get their needs met in ways that have the potential for interfering with someone else's ability to get his/her needs met. ${ }^{45}$ At this juncture one recalls 'striving' in Wallensteen's definition of conflict discussed above. In other words, this refers to parties 'doing something', however minimal, in ways that have the potential to limit the share of the other in the 'pie' (scarce resource) which is sought after by two states. ${ }^{46}$

Some real issues lurking behind the border conflict form this behavioral dimension of the conflict. These include unsettled issues of economic relationship and citizenship of people of Eritrean origin. For seven years following Eritrea's independence, the two countries had an extensive economic relationship. Ethiopia continued to use the ports of Assab and Massawa. Hence, Eritrea gained port fees and charges which by 1997 amounted to a total of

\footnotetext{
${ }^{42}$ Medhane Tadesse (1999), The Eritrean-Ethiopian War: Retrospect and Prospects (Addis Ababa: Mega Printing Enterprise), p. 50, See also, John Young (1997), Peasant Revolution in Ethiopia: The Tigray People's Liberation Front (Cambridge: Cambridge University Press), p. 156, Richard Reid (2003), 'Old Problems in New Conflicts: Some Observations on Eritrea and Its Relations with Tigray, from Liberation Struggle to Inter-State War', Africa: Journal of the International African Institute 73(3), p.375.

${ }^{43}$ Bernard Mayer, supra note 15 , p. 13.

${ }^{44}$ Ibid, p. 6.

${ }^{45}$ Bernard Mayer, supra note 15, p. 5.

${ }^{46}$ Peter Wallensteen, supra note 1, p 15.
} 
$22.6 \%$ of total public revenue excluding external grants. ${ }^{47}$ Moreover, close to 300,000 Eritreans got direct and indirect employment opportunities in Ethiopia because of the close relationship between the two countries. ${ }^{48}$ An estimated 60$80 \%$ of Eritrean exports were destined to Ethiopia before the war erupted as its products did not meet the standards required in Europe or neighboring Gulf markets ${ }^{49}$. What is more, the two countries used the same currency until Eritrea introduced its own in $1997 .{ }^{50}$

The two countries had concluded a number of agreements on trade, transit and port services, communication, transportation and the like although these agreements were not comprehensive. ${ }^{51}$ Moreover, there were spheres which were not clearly agreed upon. For instance, there was no clear official articulation or exchange of ideas about how to resolve problems resulting from differences in national economic plans, access to markets, currency exchange rates and the nature of this relationship and the benefits that accrue to the people of each country. ${ }^{52}$ Although the two countries had signed an agreement on the harmonization of economic policies on September 23, 1993, it showed some signs of incompatibility from the outset and caused grievances. Particularly, people in the two countries viewed the commodity trade sector, the monetary arrangement, Eritrea's new currency and issues of citizenship differently. ${ }^{53}$

${ }^{47}$ Gote Hansson (2001), 'Building New States: Lessons from Eritrea', Discussion Paper No. 2001/66 presented at United Nations University World Institute for Development Economics Research, p. 11.

${ }^{48}$ Gilbert Khadiagala (1999), 'Reflections on the Ethiopia-Eritrea Conflict', The Fletcher Forum of World Affairs XXIII, No. 2, p. 43.

${ }^{49}$ Ross Herbert, The End of the Eritrean Exception? The South African Institute of International Affairs, 2002, Country Report No. 8, p 17 available at: http://dspace.cigilibrary.org/jspui/bitstream/123456789/29833/1/Country\%20Report $\% 20$ No\%208.pdf?1, accessed on August 4, 2012.

${ }^{50}$ Ibid, p. 9.

${ }^{51}$ Trade Agreement and Trade Protocol between the Transitional Government of Ethiopia and the Government of the State of Eritrea( Sep 27, 1993), Transit and Port Services Agreement between the Transitional Government and the Government of the State of Eritrea( Sep 27, 1993), Protocol Agreement on Transport and Communications between the Transitional Government of Ethiopia and the Government of the State of Eritrea( Sep 27, 1993), Air Services Agreement between the Transitional Government of Ethiopia and the Government of the State of Eritrea( Sep 27, 1993).

${ }^{52}$ Abebe Zegeye and Melakou Tegeng (2007), The Ethiopia-Eritrea Conflict: A

Critical Observation (Johannesburg: Institute for Global Dialogue), p. 18.

${ }^{53}$ Ibid. 


\section{a) The commodity trade sector}

One feature of the harmonization agreement was that it provided for free reexport of goods imported from third countries. Thus, for instance, Eritreans could export to Ethiopia products they imported, say, from China or India without having to pay Ethiopian customs duty and vice versa. Since the two countries did not have common external tariff, this resulted in grievances on the part of Ethiopian businesses. This was due to the very low external tariff of Eritrea as compared to Ethiopia. Because of this difference in tariff rates Eritrean businesspersons could import goods from third countries through Eritrea and sell them in Ethiopia without paying the high tariff their Ethiopian counterparts paid. This gave them a competitive edge over Ethiopians in the Ethiopian market and caused bitter complaints. Various Eritrean writers, however, expressed a totally different view. According to Alemseged, this arrangement benefited Ethiopia more because, the goods re-exported to Ethiopia were bought using meager Eritrean hard currency but sold for Ethiopians in Birr, a soft currency. ${ }^{54}$

The other feature of the harmonization agreement was that it provided for free movement of goods and services except those that were in short supply between the two countries. The Eritrean side found this restriction on "goods in short supply", which was an Ethiopian inclusion, difficult to understand and work with. The complaint was that any product could be so declared at any time, thus hampering free trade in goods. ${ }^{55}$ The complaint on the Ethiopian side was that Eritrea was abusing the agreement in respect of free movement of goods to export Ethiopian products to third countries and thus getting hard currency at the expense of Ethiopia in contravention of another provision of the treaty that prohibited such conduct. The perception of certain sections of the Ethiopian society was that Eritrea had become one of the 'biggest exporters of coffee' in the world although it does not grow coffee at all. ${ }^{56}$ For instance, Capital, a weekly Ethiopian Newspaper in its March 20, 2011 issue states that Eritrea ranked the $13^{\text {th }}$ biggest exporter of coffee before the outbreak of the 1998 war although it does not produce coffee at all. ${ }^{57}$ Such perceptions complicated relations even if they were at times exaggerated.

\footnotetext{
${ }^{54}$ Alemseged Tesfai, The Cause of Eritrean-Ethiopian Conflict, available at: $<$ http://www.denden.com/Conflict/newscom/com-alem98.html $>$, accessed on August 7, 2012.

55 Tekeste Negash and Kjetil Tronvol (2000), Brothers at War: Making Sense of the Eritrean Ethiopian War (Ohio University Press), p. 32.

${ }^{56}$ Abebe Zegeye and Melakou Tegeng, supra note 52, p19.

${ }^{57}$ Solomon Bekele, 'Africa: the continent of billionaires', Capital, Year 13, Issue 640, p 32.
} 
Due to the foregoing reasons, it was clear by 1996 that the implementation of the 23 protocols signed by the two countries in 1993 was greatly hampered.$^{58} \mathrm{~A}$ joint review committee was thus set up. Tekeste and Tronvoll summarize the problems identified by the committee as follows: ${ }^{59}$

i. Restrictions had been imposed on Eritrea's import of Ethiopia's exportable products.

ii. There was a serious lack of adequate institutional mechanisms to implement the agreements reached.

iii. No action had been taken to combat illegal trade.

iv. Several types of local charges and intermediate payments had been introduced.

v. Licensing systems were different and discriminatory.

\section{b) The monetary arrangement}

Pursuant to Article 1 of the Harmonization Agreement, the two countries used the Ethiopian currency (the Birr) until Eritrea issued its currency in November $1997 .{ }^{60}$ The view in Eritrea was that Ethiopia benefited more from this arrangement. For Eritreans, using the Birr meant de facto currency union, without however allowing Eritrea voice in Ethiopia's conduct of monetary policy, thereby putting Eritrea at a disadvantage. This was the case, it is maintained, because the interest rates set by the National Bank of Ethiopia was not necessarily appropriate to business conditions in Eritrea ${ }^{61}$ Second, without its own currency, Eritrea had no seignorage revenue, ${ }^{62}$ and this factor was regarded as an important consideration given the need to finance reconstruction and development spending.

Ethiopia on the other hand viewed this arrangement as relatively more beneficial to Eritrea. The view was that Eritrea was paying in soft currency, i.e, in Birr, for Ethiopian products as well as for products Ethiopia imported using its meager hard currency. The result of all this led to a deeply held belief that Eritrea was siphoning off Ethiopia's economic resources. ${ }^{63}$ The pressure on the Ethiopian government thus was to require Eritrea as a sovereign country to shop around for resources in the same way as Ethiopia does.

\footnotetext{
${ }^{58}$ Tekeste Negash and Kjetil Tronvoll, supra note 55, p. 33.

${ }^{59}$ Ibid.

${ }^{60}$ Alemseged Tesfai, supra note 54.

${ }^{61}$ Hansson, supra note 47, p. 7.

${ }^{62}$ This is the profit obtained from minting coins/printing money if the cost of producing say a bill or coin is less than the worth of the bill or coin as the case may be. It is possible for the costs to exceed the value of the coin, in which case the government will incur loss.

<http://www.investopedia.com/terms/s/seigniorage.asp\#axzz22qtWBqoa>, accessed on August 7, 2012.

${ }^{63}$ Ruth Iyob (2000), supra note 35, p. 667.
} 


\section{c) Eritrea's introduction of new currency}

In 1997 Eritrea introduced its own currency, Nakfa. This, according to Eritrean authorities, was necessitated by the divergent fiscal, trade and investment policies the two countries had begun to follow. There was lack of transparency in the way the Nakfa was introduced. For instance, no understanding was reached about its relationship to the Ethiopian Birr. Thus, when the currency began to circulate, the Ethiopian government refused Eritrea's request for Nakfa-Birr parity. It asked Eritrea to conduct trade using hard currency and Letter of Credit (LC) unless it merely involves border trade not exceeding 2000 Birr. ${ }^{64}$ Eritrea rejected Ethiopia's proposal to trade by Letter of Credit. ${ }^{65}$

According to some Eritreans, the Nakfa-Birr parity 'controversy' was actually an Ethiopian creation. All Eritrea requested was 'free convertibility', i.e., to give traders in both countries the opportunity to agree on the use of the currency of their choice for settlement. It did not request parity of the two currencies. ${ }^{66}$ Other Eritreans admit that Eritrea did request the parity of the two currencies. Moreover, they allege that Ethiopia had accepted that or at least 'Eritrean officials had naively believed' it before the issuance of the Nakfa. ${ }^{67}$ The contention that Eritrea did not request Nakfa-Birr parity seems to be a postfacto argument aimed at buttressing the stand of Eritrea on this issue as the demand for party was found to be flying in the face of logic.

\section{d) The Issue of citizenship}

The two countries have divergent laws regarding the issue of nationality. Eritrea recognizes anyone of Eritrean parentage on paternal or maternal side as its citizen. In fact, the Eritrean law envisages the possibility of having multiple citizenships although some extra procedures have to be complied with ${ }^{68}$ while Ethiopia does not. According to Article 11 of the 1930 Ethiopian nationality law (that was in force at the time of the conflict), any person who acquires another citizenship immediately forgoes Ethiopian citizenship. Since the two countries never took legal steps to put matters to rest in this regard, problems began arising. The problem was broad, as all Eritreans had Ethiopian citizenship and

\footnotetext{
${ }^{64}$ Hansson, supra note 47, p.11.

${ }^{65}$ University of Pennsylvania African Studies Center, Horn of Africa Monthly Review, 3-4/98, March to April 8, 1997 issue, available at: <http://www.africa.upenn.edu/Hornet/HOA0398p.html> accessed on August 7, 2012.

${ }^{66}$ Alemseged Tesfai, The Causes of Eritrean Ethiopian Conflict, supra note 54.

${ }^{67}$ Ruth Iyob (2000), supra note 35, p. 674.

${ }^{68}$ The Eritrean Nationality Proclamation no 21/1992, Art 2(5) available at: <http://www.unhcr.org/refworld/docid/3ae6b4e026.html> accessed on Aug. 4, 2012.
} 
no arrangements were set in place to identify who among them have adopted Eritrean citizenship. ${ }^{69}$

Thus, in the Joint High Ministerial Commission, Ethiopia voiced its concern over a significant number of Eritreans still carrying Ethiopian passports and requesting renewals. This situation created problems especially in the issuance of licenses for investment in sectors such as the banking and insurance industries reserved for Ethiopian nationals alone. To put it simply, the Ethiopian side felt that Eritreans were taking unfair advantage of the free movement, residence and business agreements by being treated as nationals in both countries while Ethiopians were not. Some Ethiopians were particularly resentful because Eritrea had, in 1991-2, expelled about 120,000 Ethiopians without meaningful protection to their rights. $^{70}$

Establishing the veracity of each allegation above is not the purpose of this article. Its objective is limited to showing the kind of behavioral issues that were lurking behind the border war.

\subsubsection{The emotional dimension of the conflict}

The emotional dimension refers to an emotional reaction to a situation that signals a disagreement of some kind. ${ }^{71}$ At the foundation of this dimension is the contention that men and groups do not act only, or in fact to a large measure, to achieve conscious objectives. In other words, subconscious or unconscious attitudes and behavior patterns constitute their more important aspects. In this view, behind the state is the nation. The latter implies a group whose members feel as a unit of some kind and react spontaneously in ways that can cause and perpetuate war or lesser forms of conflict in response to encroachment, real or imagined. ${ }^{72}$ Wars, therefore, can be considered in some cases as clashes between identity groups.

This third, emotional/identity dimension of international conflict began to get attention in recent decades. Instead of viewing international conflict as struggles over resources only or 'as the hard shells of nation-states bouncing off each other', a new view suggested that conflicts 'were just as often struggles within and between nations over contending ideologies, values, needs and most fundamentally, identities.' In this context, identity represents "people's need to preserve a sense of who they are and what their place in the world is", and it plays a major role in conflict. ${ }^{73}$ When a group is in conflict or at war with a

\footnotetext{
${ }^{69}$ Ruth Iyob (2000), supra note 35, p. 664.

${ }^{70}$ Ross Herbert, supra note 49 p. 32.

${ }^{71}$ Mayor, supra note 15 , p. 5.

${ }^{72}$ Wright, supra note 9, p.111.

${ }^{73}$ Mayer, supra note 15, p.19.
} 
neighbor, group members become acutely aware of their large group identity to the point where it may far outweigh any concern for individual needs, even survival. $^{74}$ Hence, members of the group rally around a leader without questioning his leadership. ${ }^{75}$

In other words, the new assumption is that the need for recognition, meaning and self-esteem, as well as the need to be 'right' could be the root cause of conflict. So, in this outlook, the economic man fighting to produce or control resource is viewed as a full-blooded being with hopes, fears, goals, values, needs and identities. So, identity is now a focus in conflict analysis and resolution. ${ }^{76}$

According to analysts who regard self-image or identity as a crucial factor in conflicts, there is the rigidity of a group's need to be 'right' about the other and the events surrounding the conflict, and there is also a desire to place the blame, for what caused the conflict and what happened during the conflict, on the other group in the conflict. The analysts maintain that there is a reflexive reaction to put all the responsibility onto the 'aggressive and evil other' to protect one's righteous self-image. This mutual deflection of responsibility by the two groups in conflict is a powerful reaction to protect one's self-image or identity and to protect oneself from the trauma related with conflict. This is an aspect of the emotional dimension of conflict causing and fueling conflicts. ${ }^{77}$

But can countries be in conflict along the emotional or identity dimension? Mayer answers this in the positive and rightly so. The Ethio-Eritrean conflict has this dimension. However, this is not meant to say that everyone in the two countries had similar emotions. Mayer's caution in this regard is pertinent. He notes that when one says two countries are at conflict along the emotional dimension it does not mean that every individual member of each country shares the same feelings or even that the majority do. It rather means that the conflict evokes certain reactions and attitudes from the dominant leaders or a significant number of people in each country. ${ }^{78}$ This point should be particularly emphasized in the Ethiopian context. Given the size and diversity of the country

\footnotetext{
${ }^{74}$ Vamik Volkan (1997), Bloodlines: From Ethnic Pride to Ethnic Terrorism (New York: Farrar, Straus and Giroux), p. 25.

75 Ibid, p. 27.

${ }^{76}$ Jay Rothman and Marie Olson (2001), 'From Interests to Identities: Towards a New Emphasis in Interactive Conflict Resolution', Journal of Peace Research 38(3), at pp.294-295.

77 Donna Hicks (2001), 'The Role of Identity Reconstruction in Promoting Reconciliation', in Raymond Helmick and Rodney Petersen (eds.), Forgiveness and Reconciliation, (Philadelphia: Templeton Foundation Press), p.139.

${ }^{78}$ Mayer, supra note 15, p.7.
} 
and its people, some sections of the Ethiopian society had little emotional involvement in the conflict. ${ }^{79}$

In the course of examining the Ethio-Eritrean conflict, one is struck by the anger, pride, betrayal and generalized hostility it has entailed. Thus, EthiopianEritrean discourse both formal and informal has been acrimonious and revolves around the emotive issue of 'betrayal' ${ }^{80}$ Participants of the field study confirm this observation. Asked how much role emotions played in fueling the 19982000 war, an overwhelming number of Eritrean and Ethiopian respondents said it had a role. Of the 96 Eritreans that answered this question, 46 said emotions played very big role while 38 said they played big role. Only 8 respondents thought emotions did not play any role. So, $91.7 \%$ of Eritrean respondents replied that emotions had very big role, big role or some role in fueling the conflict. Ethiopian respondents too confirmed that emotions had significant role in the conflict. On the Ethiopian side 42 out of 70 respondents said emotions had very big role, 16 said they had big role while 2 respondents said they had some role. Only 10 respondents said emotions had no role in fueling the war.

Regarding self-image or identity on the Ethiopian side, one notes significant section of the society feels a strong sense of pride over the country's almost uninterrupted independence for long time. The victories achieved in several wars fought against the Turks, Egyptians, Mahdists, Italians, etc... who tried to invade the country, are gloriously remembered, and to some extent mystified. Some segments of the society justify this by ancient and biblical myths portraying Ethiopians as a chosen people. ${ }^{81}$ A military challenge by Eritrea, formerly only a province of Ethiopia, was therefore, an affront. In short, there was a high degree of symbolism involved in the war. Thus, for Ethiopians negotiating before Eritrea's withdrawal from the territory it occupied by force was compromising their identity. The speech made just after the outbreak of the conflict by Ato Ghebru Asrat, President of the Regional State of Tigrai (during the period) illustrates this point. He said ${ }^{82}$ :

...we will pay any kind of sacrifice, even if the war takes spans of generations. No force can invade us! Impossible! This is because Ethiopia means 'anti-invasion'. An Ethiopian means one who dies for his honor and fights for freedom and independence.

\footnotetext{
${ }^{79}$ Informal discussion with Ethiopians of diverse background indicates this fact. The Eritrean Government further extends this reality to portray the conflict as a conflict which does not involve most Ethiopians as such.

${ }^{80}$ Ruth Iyob (2000), supra note 35, p.678.

${ }^{81}$ William Scott (1993), The Sons of Sheba's Race:African Americans and the ItaloEthiopian War, 1935-41 (Indianapolis: Indiana University Press), p. 23.

${ }^{82}$ Kjetil Tronvoll, supra note 36, p. 66.
} 
This feeling was shared by a significant number of Ethiopians. It was not uncommon to hear a common man treating the conflict as an affront to identity of Ethiopia and Ethiopians. Tronvol presents what an elderly peasant from the outskirts of Mekelle told him. The peasant said: "The present 'habo' (resolve in the face of difficulty) is even greater than in the past because Eritreans ... have shown their contempt for us by stating that they are better than we are, and have taken our land". ${ }^{83}$

The survey conducted by this author in Shire-Indaselassie and Addis Ababa confirmed the role of self-image and identity in the conflict. To assess the extent to which issues of self-image fueled the 1998-2000 war, four questions were put to participants of the study. They were asked whether the war was really a border war, and particularly what they thought on this issue during the war, whether or not ethnic/regional feelings were apparent during the war and the extent to which people felt the need to win the war irrespective of who started it. The answers to these questions indicated that the war was not really seen as a border war. For instance, 64 out of 68 Ethiopian respondents said the war was not a border war. 34 out of 62 participants said they felt the war was not a border war even at the time of the war. Moreover, 48 out of 69 respondents said ethnic or regional feelings were apparent during the war and 60 out of 68 respondents said the need to win the war irrespective of who started it, played a very big role in fueling the conflict while the remaining 8 did agree this had a role but only 'some' role. Although the survey was not meant to make generalizations about the entire populations of the two countries, the figures indicate that the conflict, to a significant extent, involved issues of self-image and identity at least to certain segments of the societies.

As regards Eritrea, one notes that Eritreans, both at home and in diaspora are imbued with a strong sense of nationalism. According to some written and oral sources, Fascist propaganda and policy of divide and rule has succeeded in instilling the feeling of superiority in the Tigrigna speaking Eritrean urban elite against Ethiopians, but mainly over Tigray owing to its geographic and cultural proximity to Eritrea. The Italians were engaged in intensive propaganda which claimed that Eritreans were superior to the people south of the Mereb in 'intelligence, creativity, moral virtues and will-power'. It has been alleged that some archives in Rome indicate that in the last years of the 1930s the Italians went to the extent of banning intermarriage between people on the two sides of the Mereb, the justification being 'biological difference'. Some contend that this racist propaganda appealed to some of the Eritrean urban elite hence they began

${ }^{83}$ Ibid, p. 67. 
to develop a distorted self-image. ${ }^{84}$ In the course of solidifying the Eritrean selfimage, the EPLF has further reinforced this problem thereby steadily letting it develop into a political culture. ${ }^{85}$

Volkan's view on identity formation seems to partly explain the Eritrean situation. According to him, a new nation may define its identity around a 'chosen trauma' and/or 'chosen glory.' A 'chosen trauma,' as used by Volkan, reflects a large group's unconsciously defining its identity by trans-generational transmission of injured selves infused with the memory of the ancestor's trauma. $^{86}$ Eritreans feel highly victimized by the Ethiopian state due to the heavy-handed and undemocratic methods that were used to emasculate and silence the opposition to unity, thus gradually alienating the Eritrean population. They had also experienced real and perceived discrimination in connection with jobs and other opportunities. ${ }^{87}$ As the Ethiopian state was using unrestrained power for thirty years in its attempt to suppress the separatist movement, many concur that the key element in the process of the formation of nationalism is a consensus that defines the common, and usually 'alien enemy'. There is thus little question that modern Eritrean nationalism is a by-product of Ethiopian hegemonic domination, according to many sources. ${ }^{88}$

As a result of the identity formed around this collective victimization, many Eritreans saw the border conflict as another attempt to humiliate them. One of the questions put to Eritreans was whether the 1998-2000 war had the effect of opening old wounds caused by previous Ethiopian governments to the Eritrean people. Of the 90 Eritreans that answered this question 74 answered yes. They saw the 1998 war as a continuation of past injustice inflicted, in their view, by the Ethiopian state. This was a strong obstacle to negotiating a settlement.

The identity that Eritreans formed around their real and perceived achievements during the armed struggle for independence also contributed to the failure to negotiate a settlement to the conflict. As Volkan explains, 'chosen glory,' the mental representation of a historical event that induces feelings of success and triumph, can be a basis for identity of a large group. He observes

\footnotetext{
${ }^{84}$ Medhane Tadesse, supra note 42, p. 36, See also Tekeste Negash, supra note 24, p.16.

${ }^{85}$ Peggy Hoyle (1997) Eritrean National Identity: The Role of Education and Constitution (Unpublished $\mathrm{PhD}$ dissertation at the University of North Carolina) $\mathrm{p}$. 56. See also Medhane, supra note 42, p. V and Tronvol, supra note 36, p.72.

${ }^{86}$ Vamik Volkan, supra note 74, p.48.

${ }^{87}$ Alemseged Abay, supra note 20, p. 224.

${ }^{88}$ Ruth Iyob (1995), supra note 28, pp. 120-21. See also Hoyle supra note 85, p.57 and Medhanie supra note 42, p. V.
} 
that the shared mental representation of a war for independence is a powerful ethnic or large-group maker. ${ }^{89}$

This view is confirmed by other writers. Endowed with battle hardened military and self-confidence, Eritrea's leader seemed eager to boost this national identity of Eritrea in every possible way. Particularly, the fact that Eritrea won its war of liberation has resulted in an elevated sense of national identity and made it a very assertive country with an ambition to exert power regionally. In some ways, it is comparable to Israel, a small nation that is very assertive. ${ }^{90}$ Many believe this phenomenon contributed to the escalation of the conflict.

Some explain the very root cause of the war as identity dilemma. Alemseged Abay, whose book on Eritrean identity was published just before the outbreak of the conflict, has the following to say:

Created in reaction to genocidal-like state behavior of [Ethiopia], Eritrean-ness remains yet to be delivered. ... Massimo d'Azeglio, once said: 'we have made Italy, now let us make Italians'. Making Eritreans and nurturing 'Eritrean-ness' demands self-definition and boundary delimitation. .... $[I]$ dentity is inherently contrastive and needs the
relevant other ...

He further contends that the Eritrean elite are searching for what Frederik Barth calls 'border guards' to separate Eritreans from Ethiopians. They have gone to the extent of renaming ethnic groups to create a rift between them and the same ethnic groups in Ethiopia. Other authors concur that concerted and conscious effort was made to 'write a liberation history.' Still others go to the extent of explaining the motive for the war itself as the desire to strengthen separate Eritrean identity. ${ }^{92}$

There is no way of telling whether the war was aimed at creating emotional scars strong enough to draw a wedge between the two people. That the war created emotional scars is, however, evident. The field study confirmed that the conflict was rife with emotions on the Eritrean side. Asked whether the 19982000 war was really a border war, 84 out of 96 Eritrean respondents said it was not. They were further asked whether ethnic or regional feelings were apparent during the war, to which 68 out of 86 persons (who responded to this question) said yes, while $21 \%$ answered no. Asked to what extent the desire to win the war, irrespective of who started it, fuelled the war, 72 out of 90 respondents said such feelings played a very big role, while 10 respondents said it played some

\footnotetext{
${ }^{89}$ Volkan, supra note 74, p. 82.

${ }^{90}$ Khadiagala, supra note 48, p. 43.

${ }_{91}$ Alemseged Abay, surpra note 20, p. 225.

92 Tekeste and Tronvoll, supra note 55, pp.30-31, See also Berhane, supra note 19, p. 34. See also Alemseged Abay, supra note 20, p. 226.
} 
role. Only 4 out of 90 respondents answered that it had no role. Obviously, the sample was not really representative of the entire Eritrean public and hence no claim is being made about the exact proportion of Eritreans who shared these feelings. However, the figures reflect the emotional aspects of the war.

This was further confirmed by interviews conducted with Ethiopians who were 'deported' from Eritrea. Interviews with returnees confirmed that particularly after the fall of Barentu the biggest threat to their personal safety was the Eritrean public, especially the youth and militia. Angesom, who was born and raised in Gindai, a town between Asmara and Massawa, told me a compelling story of his own. He said he witnessed brutal beating of civilian Ethiopians. In fact, he himself had to run for his life into a police station. $.^{93} \mathrm{~W} / \mathrm{ro}$ Tsaidu, an elderly deportee, told me of another incident. She said that when they were being transported to Ethiopia, the Eritrean public would throw stones at their buses. For instance, she said this happened at Maihabar. ${ }^{94}$ Almost all other interviewees in Adigrat and Mekelle confirmed that such occurrences were very prevalent after the fall of Barentu to Ethiopian forces, and this was particularly worse outside Asmara.

In light of the foregoing, the conflict should not be seen only as state-to-state conflict devoid of emotions and identity issues.

\subsubsection{Cognitive dimension of the conflict}

The cognitive dimension refers to a belief or understanding that one's own 'needs, interests, wants or values are incompatible with someone else's' ${ }^{95}$ In other words, this refers to what the parties to a conflict think about the motives and activities of each other. It could, for example, be a belief in country ' $A$ ' that country ' $\mathrm{B}$ ' is working to destabilize the former, and the vice-versa. This perception could cause and fuel conflict. At the root of this dimension of conflict is the sociological principle that "action always proceeds ... from the interpretation of conditions by decision makers. In other words, action comes from image in the mind". ${ }^{96}$

On the part of Eritrea the perceptions were, to significant degree still are, that Ethiopia and Ethiopians still think Eritrea is by nature and logic part of Ethiopia and thus want Eritrea to fail as a sovereign entity. ${ }^{97}$ The views of Professor

\footnotetext{
${ }^{93}$ Interview with Angessom Gebreanenia, Addigrat February 26, 2010. This interviewee also told me of the severe condition under which the returnees were detained and the various techniques the Eritrean authorities would use to avoid scrutiny of this by the Red Cross.

${ }^{94}$ Interview with Wro Tsadu Berhe, Adigrat February 27, 2010.

${ }^{95}$ Mayer, surpa note 15 , p. 4.

${ }^{96}$ Wright, supra note 9, p. 254.

${ }^{97}$ Tekeste Negash and Tronvoll, supra note 55, p. 94.
} 
Tekie, a member of Eritrea's Constitutional Commission, perhaps summarizes the perception in significant quarters in Eritrea:

The TPLF, after paying lip service to the birth of Eritrea, is now trying to snuff the life out of Eritrea's sovereignty. Ethiopia's rulers past and present share the lust for the land (of Eritrea) though the TPLF is more debilitating. ${ }^{98}$

This kind of image painted by Eritrean opinion makers such as Professor Tekie seems to have been consciously created by the Government of Eritrea. An Eritrean I interviewed in Maiaynie refugee camp told me that as a young university graduate in the war years and even after that he would be required to paint this image of Ethiopia in weekly political indoctrination lessons at his workplace; he was required to incorporate in the 'lessons' how the rulers of Shoa and Tigray always tyrannized over Eritreans and that they still desire to do that. Perhaps in part owing to such indoctrination, even the common people seem to share or to have shared this outlook about Ethiopia's intentions. Summarizing the outlook after the border war, Richard Reid observes that:

[the Eritrean society is broadly] governed by the notion of destiny usually, and increasingly couched in militaristic terms, and by a potent sense of isolation which rests on the belief that Eritrea can trust no-one, from Ethiopia to the 'international community'; and thus 'suffering and hardship' have been and will be for some time to come the lot of the Eritrean people. ${ }^{99}$

The field study confirms the prevalence of negative perceptions at the time of the war. Asked whether there were fears, during the war, that the real intention of the Ethiopian Government was to 're-occupy/dismember/destabilize Eritrea' 62 out of 94 of the respondents answered yes. Another rather surprising answer was asked whether Eritrean Government works to destabilize Ethiopia 44 out of 84 Eritreans answered yes.

The overwhelming majority of the respondents being Eritrean refugees living in Ethiopia one cannot claim the foregoing perceptions are representative of the larger Eritrean society. They do however indicate that the perceptions about the intentions of Ethiopia on Eritrea have improved. In an interview with the Chairperson of Maiaynie refugee camp coordinating committee, a refugee himself, he told me that perceptions have improved greatly. He notes that the number of refugees who come to Ethiopia is a good indication, and this is so,

${ }^{98}$ Tekie Fessehatzion (2002), Shattered Illusion, Broken Promise (Lawrenceville: Red Sea Press), p.252.

${ }^{99}$ Richard Reid (2005), 'Caught in the Headlights of History: Eritrea, the EPLF and the Post-War Nation-State', Journal of Modern African Studies 43(3), p. 468. 
despite the intense propaganda by the Eritrean government that the Ethiopian government injects HIV into the body of Eritrean refugees and similar horrifying stories. According to him, a few years back many Eritreans feared coming to Ethiopia because of the negative perceptions actively fostered by Eritrea. Moreover, fleeing to Ethiopia was considered extremely unpatriotic, while today it is absolutely a different story. ${ }^{100}$

Similarly, a significant number of Ethiopians believed that Eritrea wished to manipulate the Ethiopian economy to the maximum benefit of Eritrea despite its declaration of sovereignty. Moreover, they believed, that Eritrea had an undeclared design to destabilize Ethiopia and weaken its economy through intermittent skirmishes which would sap the nation's resources that are essential for development. Asked what the intentions of Eritrea were at the time of the war, 50 out of 70 Ethiopian respondents in the survey said that the Eritrean Government wanted to destabilize and dismember Ethiopia. They believe that Eritrea foments dissidence and insurgency in Ethiopia by training and arming various fundamentalist and separatist groups. ${ }^{101}$ Today, the perception has worsened. Asked about the current intentions of Eritrea, 52 out of 68 of Ethiopian respondents said Eritrea now works to destabilize and dismember Ethiopia. Many Ethiopians also contend that Eritrean daily broadcasts in several Ethiopian languages corroborate the existence of a design to destabilize Ethiopia.

\section{The Boundary and Claims Commissions: A Cursory Look at Their Mandates and Awards}

The two countries solely took a purely legalistic approach to solve their conflict. The Algiers agreement, signed on December 12, 2000, which terminated the war provided for the establishment of two arbitral tribunals: the Boundary Commission and the Claims Commission. ${ }^{102}$ Each had to base all its decisions on relevant rules of international law. Particularly, the Boundary Commission was given mandate to delimit and demarcate the border between the two countries on the basis of the 1900, 1902 and 1908 treaties between Italy and Ethiopia and applicable international law. ${ }^{103}$ Similarly, the Claims Commission had the mandate to give awards on all claims for loss, damage or injury resulting from $^{104}$ (a) the actions of one government against the other, (b) the actions of the

\footnotetext{
${ }^{100}$ Interview with Misgina MaiAyni Refugee Camp, February 22, 2010.

${ }^{101}$ Paul B. Henz, Eritrea's War Against Ethiopia: Causes and Effects, Reflections, Perspectives at <http://www.fas.org./man/dod-101/ops/war/docs/02501001.htm>

102 The Agreement between the Government of the Federal Democratic Republic of Ethiopia and the Government of the State of Eritrea, Articles 4 and 5.

${ }^{103}$ Id. Art 4(2).

${ }^{104}$ Ibid. Art. 5(1).
} 
nationals of either party against the government or entities owned by the other government, and (c) violations of international humanitarian law. The Tribunal did not have jurisdiction to hear claims arising from the cost of military operations, preparing for military operations or the use of force, except to the extent that such claims involved violation of international humanitarian law. ${ }^{105}$ Neither Commission had the power to make decisions ex aequo et bono. ${ }^{106}$

The Boundary Commission embarked on its task by underscoring that it will stick to the terms of the Algiers agreement and rely on the three boundary treaties and international law, with a caveat that international law attaches significance to the conduct of parties to a treaty subsequent to conclusion of a treaty. It observed ${ }^{107}$ :

The effect of a subsequent conduct may be so clear in relation to matters that appear to be the subject of a given treaty that the application of an otherwise pertinent treaty provision may be varied.... The nature and extent of the conduct effective to produce a variation is, of course, a matter of appreciation by the tribunal in each case.

On the basis of the above understanding of its mandate and applicable rules, it considered the claims of each side as to where exactly the boundary between the two countries should be. It then rendered its decision on April 13, 2002. The scope of this article does not allow delving into the details of the decision other than a brief indication of two points. The first is that each state won some territories the other had claimed, and the territories won or lost by each were not particularly vast or endowed with proven resources. The second is that Badme the flashpoint of the conflict was awarded to Eritrea although this was not clearly mentioned in the award itself. ${ }^{108}$

As regards the work of the Claims Commission, one should note that the issues pending before it were many, diverse and complex. Dealing in detail with the claims of each country is clearly beyond the themes of this article. Hence, we will be confined to highlighting the types of claims and the awards given.

${ }^{105} \mathrm{Id}$.

${ }^{106}$ Id. Art. Art 4(2) and 5(13).

${ }^{107}$ Ethiopia-Eritrea Boundary Commission Decision Regarding the Delimitation of the Border Between the State of Eritrea and The Federal Democratic Republic of Ethiopia, Paragraphs 3.8 and 3.9 (pages 22 and 23) available at: <http://www.eritreahilfswerk.de/fileadmin/Daten/pdf/eebc_decision-l.pdf> Accessed on May 4, 2012.

${ }^{108} \mathrm{Ibid}$, Par 8.1 and 8. 2 (pp. 97 to 104). For a quick view of the final boundary decision one is advised to look at these pages and maps 10, 11 and 12 included in the award of the Commission itself. 
Ethiopia claimed, among other things, that Eritrea waged war against it in violation of the UN Charter that bans the use of force. ${ }^{109}$ The claim accuses Eritrea of violation of the laws of war and killed, raped, tortured, abducted, physically and mentally abused, forcefully displaced, interned, subjected to frequent beatings, Ethiopians in Ethiopian territory it occupied in the initial months of the war and within Eritrea. Ethiopia further claimed that Eritrea was engaged in shelling and aerial bombardment of civilian targets. Ethiopia's contention was that in the aggregate, almost 242,000 people were potentially exposed to these violations. ${ }^{110}$

Other claims included execution and mistreatment of Ethiopian prisoners of war, ${ }^{111}$ confiscation of cargoes from Ethiopia that were in Eritrean ports at the start of the war, taking property of Ethiopians in Eritrea ${ }^{112}$, causing economic loss throughout Ethiopia by starting the war, ${ }^{113}$ and mistreatment of Ethiopian Embassy personnel and interference with access to Ethiopian Embassy in Eritrea. ${ }^{114}$ On the basis of the above allegations, Ethiopia claimed total damages amounting to 14.3 billion USD. This amount, according to the Claims Commission, was more than three times the Gross National Product of Eritrea in 2005 measured on purchasing power parity. ${ }^{115}$

Eritrea on its part claimed, among other things, that Ethiopia breached the laws of war especially after occupying Eritrean territory following its May 2000 offensive. The claims included destruction and looting of property, abuse of civilians which in some instances like Teseney and Barentu included rape, and shooting of civilians. ${ }^{116}$ Eritrea claimed that Ethiopia caused internal displacement of thousands of civilians in Eritrea and prevented their return to their homes. ${ }^{117}$ Eritrea further claimed that Ethiopia engaged in aerial bombardment of six towns causing civilian casualties and loss of property, targeting infrastructure, for instance, water reservoir and power station near Assab and Massawa respectively. ${ }^{118}$ Other claims stated that Ethiopian troops were engaged in desecration of cemetery of Eritrean patriots and have damaged the historic stela at Matara. ${ }^{119}$ Yet another major claim of Eritrea was that Ethiopia violated the rights of Eritreans and Ethiopians of Eritrean origin living

109 Jus Ad Bellum, Ethiopia's Claim 1-8.

${ }^{110}$ Final Award for Ethiopia paragraphs 76 and 77.

${ }^{111}$ Ethiopia's Claim 4.

112 Ethiopia's Claim 6.

${ }^{113}$ Ethiopia's Claim 7.

${ }^{114}$ Ethiopia's Claim 8.

${ }^{115}$ Damage Award for Ethiopia, Section III, Paragraph 18.

${ }^{116}$ Eritrea's Claim 3 paragraphs 26 and 28.

${ }_{117}$ Eritrea's Claim 14, Paragraph 122 and Claim 21, Paragraph 131.

${ }^{118}$ Eritrea's Claim 26, Paragraph 99 and 107.

${ }^{119}$ Eritrea's Claims 2,4,6,7,8 and 22. 
in Ethiopia at the outbreak of the war by wrongfully denationalizing them, expelling them en mass, detaining them without due process and depriving them of their property in violation of international legal obligations. Regarding the numbers affected, Eritrea alleged that 75,000 persons were expelled from Ethiopia. ${ }^{120}$ Other claims of Eritrea included deliberate killing, physical and mental abuse of Eritrean prisoners of war, that Ethiopia ceased to pay pension to Eritreans who were in the service of the Ethiopian state prior to the independence of Eritrea ${ }^{121}$ and that Ethiopia was engaged in a systematic confiscation of business, real property, trucks and other property of Eritreans in Ethiopia. ${ }^{122}$ On the basis of these claims, among others, Eritrea requested an award approaching 6 billion USD against Ethiopia. ${ }^{123}$

The Commission decided on each claim and gave awards. The awards given in respect of each claim filed by the two countries are voluminous and they cannot be presented in meaningful details here. We thus confine ourselves to highlighting five observations. These are ${ }^{124}$ :

a) Neither side got all it wanted. In fact, both sides were found to have committed serious violations of international humanitarian law;

b) The violations of international humanitarian law committed by Eritrea were in some sense more egregious as they were mostly directed at the life and limb of the victims. The Commission found Eritrea liable for severe crimes like unlawfully killing or permitting the killing, rape and abduction of civilians. It also found it liable for abuse and improper care for Ethiopian prisoners of war and failure to give proper protection to civilians it expelled in addition to looting civilian property.

c) The Commission found Ethiopia liable for failure to give proper protection and treatment to Eritrean prisoners of war, for indoctrinating them, for improperly detaining and expelling Eritreans from its territory, engaging in looting and unlawful destruction of property.

${ }^{120}$ Eritrea's Claims 15, 16, 23, 27, and 32.

${ }^{121}$ Eritrea's Claims 15, 17 par 3, 19 and 23.

${ }^{122}$ Eritrea's Claim 24.

${ }^{123}$ Eritrea Final Award for Damages, Paragraph 18.

${ }^{124}$ Read the awards available at: <http://www.pcacpa.org/showpage.asp?pag_id=115>, accessed on May 15,2012. Of particular interest in this regard are: Partial award, Western and Eastern Front-Ethiopia's Claims 1 and 3, Partial Award: Central FrontEthiopia's Claim 2, Partial Award: Prisoners of War:-Ethiopia's Claim 4, Partial Award: Civilian Claims- Ethiopia's Claim 5, Partial Award: Prisoners of warEritrea's Claim 17, Partial Award: Central Front-Eritrea's Claims 2,4,6,7,8 and 22, Partial Award: Civilian Claims-Eritrea's Claims 15,16,23, and 27-32, Partial Award Jus Ad Bellum, Ethiopia's Claims 1-8; Final Award Eritrea's Damages Claim Sec IX, Parag 21; Ethiopia's Damages Claims Final Award, Sec XII E. 
d) The Commission found Eritrea liable for starting the war in violation of Article 2 paragraph 4 of the Charter of the United Nations by resorting to the use of force; and,

e) On the basis of the foregoing findings, among others, and on the basis of its understanding of the rules of international law dealing with determination of the quantum of compensation it awarded Ethiopia a total monetary compensation of USD 174,036,520; and it awarded Eritrea and its named nationals a total of USD 163,520,865.

\section{The Mismatch between the Eritrea-Ethiopia Conflict and Its Arbitration}

According to Wallensteen, conflict resolution is a situation "where the conflicting parties enter into an agreement that solves their central incompatibilities, accept each other's continued existence as parties and cease all violent action against each other". ${ }^{125}$ In the context of conflict resolution, acceptance of each other's continued existence implies a situation wherein parties to the conflict accept each other as parties to future dealings with one another. ${ }^{126}$ Conflict resolution also means more than the absence of war or fighting. The parties are agreeing to respect each other and to live together. However, it may or may not include broader meanings of peace such as cooperation, integration and justice. ${ }^{127}$

Contemporary views of conflict resolution take a broad view of the nature and timing of intervention in conflicts. While the classical view of conflict resolution focused on intervention addressed at the core parties to the violent conflict, the contemporary view emphasizes the 'bottom-up' process. ${ }^{128}$ In general, there has been a shift from seeing a third party intervention as the primary responsibility of outsiders to appreciating the role of indigenous peacemakers. Instead of outsiders offering a solution to a conflict say in oneshot arbitration or even mediation, the emphasis is now on the need to build constituencies and capacity within societies that aim at managing conflicts in a sustained way. ${ }^{129}$

The idea behind this approach is that in societies or even countries that are in conflict you have people involved in the conflict to different degrees. Certain segments of the society will be more invested in the conflict than others. You will thus have core parties to the conflict, at the very center of the conflict. Next to this layer you will have actively influential parties, the second layer. The third

\footnotetext{
${ }^{125}$ Wallensteen, supra note 1, p. 8.

126 Ibid.

127 Ibid., p. 9.

${ }^{128}$ Ibid, p. 23.

${ }^{129}$ Ibid, p. 25.
} 
layer consists of marginal parties to the conflict. The fourth layer may consist of 'uninvolved' parties. This latter group is a party to the conflict in a minimal sense and is not meaningfully absorbed in the conflict. All these groups can play their own roles in resolving a conflict. In other words, the new approach sees working from the outside layer towards the key or core parties to the conflict as an option that has to be taken in tandem with focusing on the core group. ${ }^{130}$ The essence of this new approach is that there are various tracks to conflict resolution. For instance, where two countries are involved in a conflict, you could work on the top leaders in the two countries. This is Track I. You can also work with middle level leaders in the two countries with the assistance of say international NGOs, churches, academics, Track II. Further down it is possible to work at local community level or at grassroots, Track III. ${ }^{131}$

In all the three tracks to peace what needs to be done to attain resolution of conflict could vary depending on the type and extent of the conflict. Where the conflict had emotional/identity dimension, for example, concrete steps must be taken to address the need for recognition, esteem and respect for each of the parties. Hence, for example, where the conflict resulted in death or created other injures steps must be taken to condemn the injustice, bring perpetrators to justice and as far as practicable 'compensate' the victim or show empathy and recognition. In other words, rectificatory justice is important. Mani writes this type of justice after conflict could have three rationales, namely, legal, political and psychosocial. ${ }^{132}$

Track II and III methods, also known as Track II and III diplomacy, complement the official Track I method that focuses on government to government relations. This is so because the two routes have the potential to provide social, psychological and spiritual support for the peace building endeavor. As a result of this process, some of the basic self-esteem (identity) and security needs of the parties are satisfied and wrong perceptions dispelled. ${ }^{133}$ On top of this, in more general ways, Track II and III diplomacy assists political leaders by compensating for the constraints imposed on them by the understandable pressure exerted on leaders to be strong in the face of the enemy. In other words, they foster a political environment through the education of public opinion that would make it safer for political leaders to take risks for peace. $^{134}$

\footnotetext{
${ }^{130}$ Ibid.

${ }^{131} \mathrm{Ibid}$, p. 26.

${ }^{132}$ Rama Mani (2002), Beyond Retribution: Seeking Justice in the Shadows of War (Malden: Polity Press), p. 7. See also Rothman and Olson, supra note 76, p. 295.

${ }^{133}$ Olga Botcharova, 'Implementation of Track II Diplomacy: Developing a Model of Forgiveness', in Helmick and Rodney (eds.), supra note 77, p. 284.

${ }^{134}$ Ibid.
} 
Arbitration is settlement of a dispute by a binding award rendered by an entity that is granted with such powers by the parties themselves. The award is arrived at by authoritative legal process and by considering the merits of the opposing positions. ${ }^{135}$ It is used when parties to a dispute opt to handle the conflict by legal means and precedent rather than by more political means. As a result, it allows a vindication of a winner and the humiliation of the loser. ${ }^{136}$ If objective elements linked to resources are predominant at a given point, then third party methods that facilitate a compromise or provide a judgment are appropriate. So, arbitration could be appropriate for disputes which focus on resource allocation. If on the other hand subjective elements such as misperception, emotions and miscommunication predominate, then third party activities that improve the relationship and induce problem-solving are more appropriate. ${ }^{137}$ As Bercovitch points out, as an international conflict escalates and de-escalates, different interventions will be appropriate at different stages. ${ }^{138}$

With the benefit of hindsight one can contend that it was wrong for the peace deal to choose to resolve the boundary problem by arbitration. ${ }^{139}$ According to Zondi and Rejouis, by opting for this method Ethiopia and Eritrea actually chose 'conflict settlement' over 'conflict resolution'. For them, conflict resolution is based on an analytical approach to get to the underlying causes of the problem and bring about permanent solution which as far as possible produces a win-win ending. ${ }^{140}$ So, although the choice of arbitration may have been motivated by expectations that the ruling might well be just, fair and, therefore acceptable to both parties, this winner-loser route at least in the case between Eritrea and Ethiopia has probably prolonged the conflict rather than resolve it. ${ }^{141}$

In fact, arbitration could even be another way of continuing the conflict as each side may go for arbitration in the hope that the outcome will justify the human and material costs of a war. In part because of this, arbitration on the boundary problem after a full-fledged war may be of doubtful utility. It has the potential for complicating matters further as it can produce results that fly on the face of the outcome of the fighting as was the case here. Ethiopia was literally required to snatch defeat from the jaws of victory which is politically extremely

\footnotetext{
${ }^{135}$ Bercovitch, supra note 16, p. 242.

${ }^{136}$ Ibid, p. 240.

137 Ibid.

138 Ibid.

${ }^{139}$ Sally Healy and Martin Plaut (2007), 'Ethiopia and Eritrea Allergic to Persuasion', Chatham House Brefing Paper, BP No. 07/01, p. 9.

${ }^{140}$ Siphamandla Zondi and Emmanuel Rejouis (2006), 'The Ethiopia-Eritrea Border Conflict and the Role of the International Community', African Journal of Conflict Resolution 6(2), p. 76.

${ }^{141}$ Ibid, p. 77.
} 
difficult to stomach. ${ }^{142}$ Regarding the Claims Commission, one easily notices that most of the matters brought to it were not really resource related. So, the observation that arbitration is inappropriate for non-resource focused conflict holds true as briefly shown below.

\section{The Eritrea-Ethiopia Conflict: The Three Dimensions of Resolution}

As Mayer observes, the dimensions of resolution depend on the dimensions of conflict. That is, the process of resolution occurs along emotional, cognitive, and behavioral dimensions. ${ }^{143}$ In what follows, we will look at these three dimensions of resolution and examine the ways in which the Eritrea-Ethiopia conflict can reach resolution in each of these dimensions.

\subsection{Emotional Resolution}

The emotional dimension of resolution involves both the way disputants feel about the conflict and the amount of emotional energy they put into it. ${ }^{144}$ If people experience the feelings associated with a conflict at high level of intensity, for example, same as when they were fully engaged, there is no emotional resolution. ${ }^{145}$ Although it may be easier to think of emotional resolution in terms of experience of individuals, the concept applies to systems as well. ${ }^{146}$ Unfortunately, in spite of the peace deal, arbitral awards on the disputed border and socio-economic claims, the level of misunderstanding and resentment between the two countries and people is still high. This, of course, is not the same for every segment of the people in both countries. Moreover, it does appear that emotions are subsiding among certain sections of the societies in the two countries though not to the desirable level. ${ }^{147}$

How can then those involved get over this, and look forward? Volkan suggests mourning. He observes that human nature gives this painful but ultimately effective way to let go of previous attachments, to adjust internally to

${ }^{142}$ Healy and Plaut, supra note 139, p.9.

${ }_{143}^{143}$ Mayer, supra note 15, p. 98.

${ }_{144}$ Ibid, p. 100.

${ }^{145}$ Ibid, p.101.

${ }^{146}$ Ibid, p. 103.

147 Reid, supra note 99, p. 476. According to him young, educated, urban Eritreans are increasingly blaming the Eritrean Government, rather than Ethiopia, for what went wrong while rural Eritreans and the older struggle generation, tegadelti remain apologetic. Similarly, informal discussions the author of this piece had with Ethiopians show that emotions in certain quarters still remain high though lower than previously. The closer one goes to the border the more intense the emotions. 
the absence of lost people or things and to get on with the future. He observes that humans cannot accept change without mourning what has been lost. ${ }^{148}$ Like individuals or families, large groups also mourn. Members of a group who share the same loss collectively go through a similar psychological mourning process. ${ }^{149}$ However, in some situations a shared calamity can leave members of a group "dazed, helpless and too afraid and angry to complete or even initiate a mourning process". ${ }^{150}$ When this happens, the large group that survived the ordeal passes down the memory of the tragedy and its feelings about it to its descendants. ${ }^{151}$

How can this be avoided in the Ethiopia-Eritrea context? How can the people of the two countries mourn their past losses so that they do not induce feelings of anger, humiliation and desire for revenge in the future generations? Religious leaders in both countries can play critical role in this regard. This could be by cultivating the culture of forgiveness, encouraging people to people contacts and teaching the need for peace. One recalls the initiatives by the religious leaders of the two countries with the assistance of the Norwegian Aid. ${ }^{152}$ Elders from both countries too can have a critical role.

Another but related method is suggested by Rothman and Olson. They suggest what they call 'resonance phase' as a starting point for the resolution of identity-based conflict. In this phase, disputants reflexively articulate their core concerns sought, threatened or frustrated within the conflict first to themselves and then to each other. ${ }^{153}$ The second element of this refers to affording opportunity to groups in conflict the chance to get the other's views regarding the causes of the conflict and what happened during the conflict. This implies that there should be interaction between members of the two groups in conflict to dispel the rigid views maintained by each regarding who is responsible and how to rectify the situation. In other words, where there is no interaction between the two groups, the desired outcomes to the conflict are seen in zerosum terms by each group because each side has expelled the other and the experiences of the other from one's assessment of what is 'right'. ${ }^{154}$ It is only after this has been done that the disputants can ask what they can do about their identities which are in confrontation. This process will enable the parties realize

\footnotetext{
${ }^{148}$ Volkan, supra note 74, p. 36.

${ }^{149}$ Ibid, p. 39.

${ }^{150}$ Ibid, p. 41.

${ }^{151}$ Ibid.

152 <http://www2.reliefweb.int/rw/rwb.nsf/db900SID/OCHA-64c8c8?OpenDocument>, accessed on June 2, 2010.

${ }^{153}$ Rothman and Olson, supra note 76, p. 298.

${ }^{154}$ Hicks, supra note 77, p. 142.
} 
that their identities are not mutually exclusive. Through this process they discover that their identities have points in which they mesh. ${ }^{155}$

People of the two countries should thus engage in in-depth discussion about the conflict instead of trying to forget about it. They should make known first to themselves and then interactively to each other the details of what were lost (in terms of life, liberty, property, opportunities etc...) on both sides. This may be done by organizing fora first in each country for this purpose. Then the discussion should involve people from both countries interacting with each other. For instance, both victims and perpetrators of wrong from both sides could express their feelings and motives in a forum similar to say the Truth and Reconciliation Commission of South Africa. The South African Commission was mandated with establishing as complete a picture as possible of the causes, nature and extent of the gross violations of human rights committed by all the parties to the conflict in South Africa. To this end, it conducted hearings and investigations and exposed various violations of human rights including the antecedents, circumstances, factors and context of such violations as well as the perspectives of victims and the motives of perpetrators of the crimes. ${ }^{156}$ What is more, it worked with the aim of restoring the human and civil dignity of victims by granting them an opportunity to relate their own accounts of the violations of human rights and by recommending reparation in respect of them. ${ }^{157}$

Similar fora would certainly be helpful, as having an opportunity to express feelings and having them acknowledged by others is frequently an important part of reaching emotional closure. ${ }^{158} \mathrm{~A}$ question that one may raise here is whether these multifaceted steps can really be taken given the narrow political space in the two countries. Unfortunately, at this point in time, the political space in the two countries is not wide enough for private citizens to fully engage in such activities. ${ }^{159}$ But this should not be an excuse for sitting idle. No matter how little it might appear, whatsoever is possible should be done because every little step in the right direction helps. This, of course, should be in tandem with working for the widening of political space necessary for such exercises.

${ }^{155}$ Rothman and Olson, supra note 76, p. 298.

${ }^{156}$ Promotion of National Unity and Reconciliation Act, No. 34 of 1995, Art. 3(1)(a). <http://www.doj.gov.za/trc/legal/act9534.htm〉, accessed on October 30, 2009.

${ }_{157}^{157} \mathrm{htt} / / / \mathrm{www} . d o j . g o v . z a / t r c / s p e c i a l / i n d e x . h t m$, accessed on October 19, 2009.

${ }_{158}^{158}$ Mayer, supra note 15, p. 103.

${ }^{159}$ For instance, Freedom House in its 2012 report categorizes Ethiopia as 'not free', with scores of 6 each for civil liberties and political rights, 7 being the worst possible score any country can get. Eritrea is considered to be even worse, scoring 7 each on political liberties and civil rights, hence 'qualifying' to the club dubbed 'the worst of the worst', Freedom House, Freedom in the World 2012, <www.freedomhouse.org|report|freedom-world|freedom-world-2012〉. 
Anyway, freedom is always to be claimed by the citizen, not bestowed by those in power.

Volkan suggests yet another path in addressing such dark chapters of the past in which a group or its leader asks for forgiveness from another group. He, however, cautions that this is effective only if the wronged group has already done a sufficient amount of mourning. ${ }^{160}$ Although admission of the commission of wrongs is helpful, the desired effects materialize only if such admissions are mutual, complete and widely publicized in the fora prepared for that purpose. Perhaps, this may be attempted in the Ethio-Eritrean context as long as the apology and forgiveness are genuinely offered.

\subsection{Cognitive Resolution}

From the cognitive dimension of a conflict follows the cognitive dimension of resolution. In other words, as the mental image or perception of people is a cause of conflict, it must be addressed as a necessary part of conflict resolution. As the UNESCO Constitution correctly puts it, "wars are made in the minds of men, and it is in the minds of men that the defense of peace must be constructed". ${ }^{161}$ Mayer notes that cognitive resolution occurs when the disputants believe that their key issues have been addressed. When a complete resolution in this dimension is attained, parties to a conflict change their essential views of the people with whom they are at conflict, the nature of the conflict or the issues themselves. ${ }^{162}$ In other words, disputants view the conflict as part of their past as opposed to their future. ${ }^{163}$

Assessment of the reality on the ground gives mixed results at best. Significant forces in Eritrea and Ethiopia still believe that the relationship is not improving as desired and will not improve that much in the near future. Evaluating the situation in Eritrea in 2005, Reid says, in the views of Eritreans, especially the struggle generation, no political, social or even economic development will take place unless Ethiopia is defeated militarily. ${ }^{164}$ The outcome of an online poll conducted by an Eritrean opposition website in the summer of 2012 indicates that some segments of the Eritrean society still envisage an outbreak of a full-fledged war as a possibility. Asked "what is the likelihood of full war breaking between Eritrea and Ethiopia in 2012", 259 respondents (13\% of those who responded to the question) answered "very high" while another 267 persons (yet another 13\%) responded "high". 951 and

\footnotetext{
${ }^{160}$ Volkan, supra note 74, p.226.

${ }^{161}$ Wright, supra note 9, p. 257.

162 Mayer, supra note 15, p. 99.

${ }^{163}$ Ibid, p. 98.

${ }^{164}$ Reid, supra note 99, p. 481.
} 
429 persons regarded the possibility as "very low" and "low" respectively. ${ }^{165}$ Although a clear majority of respondents believed that the possibility is very low and low, it should be noted that the question was about the possibility of full-fledged war between the two countries in 2012. This does not thus disprove the observations of Reid regarding the thoughts of a significant number of Eritreans about a renewed war as a possibility, if not a probability, in the near future.

In contrast to public opinion in Eritrea, the Ethiopian public shows a general tendency of forgetting away ${ }^{166}$ the Eritrea-Ethiopia conflict while the Ethiopian government oscillates between containment and taking proactive defensive measures. Talking to the media on March 12, 2011, the late Prime Minster Meles Zenawi indicated that the policy of Ethiopia (until that time) had been foiling terrorist and other attacks sponsored by Eritrea. He however, added "it is now difficult to hold down this force of destruction only guarding our borders". There should be, he continued, an effort to change either the policy of the Eritrean Government or the regime itself. ${ }^{167}$ The raids Ethiopia conducted inside Eritrea in March 2012 to wipeout what it called 'training camps for subversive groups, 168 can be understood in light of this change of strategy.

On the side of the Government of Eritrea the perception seems to be going from bad to worse. On March 24, 2011 the Ambassador of Eritrea to the United Nations, Araya Desta wrote to the President of the Security Council that Ethiopia has been pursuing, during the past ten years "an active policy of subversion and hostility against Eritrea under the rubric of regime change". The Ambassador then reminded the President of the arms embargo the Security Council 'unjustifiably' imposed on Eritrea in December 2009 and warned that the embargo might encourage Ethiopia to contemplate reckless acts of further aggression against Eritrea. ${ }^{169}$

The foregoing statements show that interventions at top level are difficult at least in the short run. This does not, however, mean that intervention in this track is entirely impossible. In fact, there are signs of conciliatory tone at the level of the political leadership. For example, in a recent interview with

$165<$ www.awate.com> accessed on August 2, 2012. The total number of respondent as of this date was 2,022 .

${ }^{166}$ Eritrean refugees whom the author met in Addis Ababa told him that they are bewildered to meet some Ethiopians who ask them whether they came from Asmara by plane ignorant that such thing is unthinkable.

167 Addis Fortune, Weekly Newspaper published in English, Vol. 11, No. 568, March 20, 2011, p. 46.

$168<$ http://www.bbc.co.uk/news/world-africa-17386161>, accessed on August 14, 2012.

169 <http://www.embassyeritrea.org/pressstatement /2011_March 24 ADesta PermRep of Eri2UN letter.pdf> . 
Aljezeera, Prime Minister Hailemariam Dessalegn said that "If you ask me, 'Do you want to go to Asmara and sit down and negotiate with Isaias Afwerki?' Then, I will say yes." ${ }^{170}$ He further noted that the late Prime Minister Meles Zenawi had a similar position, and said that both sides need to have the same position for this to materialize.

Yet, a solid achievement in this realm seems to be difficult in the short run. Hence, a wide range of conflict resolution mechanisms focusing on mid and grassroots levels, i.e Track II and Track III diplomacy, should become current priorities toward attaining resolution on the cognitive dimension of the conflict. This is not, however, to suggest that efforts need not be exerted at the level of the two governments (Track I). In fact, efforts at Tracks II and III are not substitutes for the engagement of governments (Track I), but rather aim at enabling the governments address the conflict.

As these tracks are underway, there should also be sub-regional, regional and global efforts to encourage and facilitate the resolution of the conflict. With regard to regional intervention, Getahun Seifu, suggests "intervention by the AU mechanisms for conflict prevention, management and resolution". ${ }^{171}$ In this regard, he points out the challenges that AU may encounter in the process such as the criticism for not defending the arbitral ruling based on the Algiers agreement and the accusation of undue influence by Ethiopia on the African Commission. ${ }^{172}$ Yet, he suggests that "AU should leave no stone unturned to intervene in the Ethio-Eritrean conflict", and that "[i]t is in the best interest of the AU (as well as the conflicting parties) to immediately ... seek peaceful resolution". 173

\subsection{Behavioral Resolution}

We usually focus on the behavioral dimension of conflict when we think of its resolution. We think of resolution "as being about what people will do (or not do) or what agreements they will make about what they will do". ${ }^{174}$ According to Mayer, behavioral resolution has two aspects. The first refers to discontinuing

${ }^{170}$ Interview with Aljezeera, December $8^{\text {th }} 2012$, $<$ http://www.aljazeera.com/programmes/talktojazeera/2012/12/20121271035462768 7.html>, Accessed: 10 Dec. 2012.

${ }^{171}$ Getahun Seifu (2012), "Ethiopian-Eritrean Conflict: Options for African Commission Intervention" in Managing Peace and Security in Africa: Essays on Approaches to Interventions in African Conflicts", (The Africa Peace and Security Programme, Institute for Peace and Security Studies, Addis Ababa University, Selected Cases in Africa, December 2012), p. 146.

172 Ibid, p. 179.

${ }^{173}$ Ibid, p. 180.

${ }^{174}$ Mayer, supra note 15, p.106. 
the conflict behavior, and its second aspect is related with instituting actions to promote resolution. He notes that "stopping fighting is one part of behavioral resolution, taking steps to meet each other's needs and implement a new mode of interaction is another". ${ }^{175}$ Mayer further observes that unless we are dealing with a conflict in which there will be no future interdependence or interaction among the disputants and in which nothing more than the cessation of certain behavior is necessary to end the conflict, then it is important to address both elements of the behavioral dimension to reach a full resolution. ${ }^{176}$

The Eritrea-Ethiopia conflict resolution must envisage the inevitability of future interaction and interdependence. This is admitted even by the late Tekie Fissehazion who was strongly opposed to any form of political union between the two countries. For instance, he is quoted as having stated that "Eritrea is not just another country. History, location and happenstance have contributed to the creation of an economic region that traverses political boundaries, so much so that economically Northern Ethiopia and Eritrea are like two siamese twins joined at the back and mutually looking in opposite directions". ${ }^{177}$

This, no doubt, is a correct observation. Thus, behavioral resolution of the conflict will require taking steps to meet each other's needs and to implement a new mode of interaction between the two countries. At this juncture, it is necessary to remember that the issues that were lurking behind the border conflict were issues like commodity trade, monetary arrangements and use of ports. So, behavioral resolution of the conflict calls for entering into a comprehensive economic cooperation that includes trade, investment, use of ports, and the mobility of people on openly negotiated terms that are fair to both sides.

\section{Conclusion}

The Conflict between Ethiopia and Eritrea is a conflict which has emotional, cognitive as well as behavioral dimensions. Arbitration as the sole means of conflict resolution on the basis of authoritative legal standards is not effective for a conflict that is permeated by emotions and adverse perceptions. Yet, Ethiopia and Eritrea opted for binding arbitration as the sole mechanism of conflict resolution. Apparently, this choice was based neither on satisfactory analysis of the causes of the conflict nor on the prognosis of the role arbitration would play in resolving the conflict. Hence, in spite of the awards rendered by

\footnotetext{
175 Ibid, p. 107.

${ }^{176}$ Ibid, p. 108.

${ }^{177}$ Tekeste Negash and Tronvoll, supra note 55, p. 92, See also Amare Tekle (1994) Ethiopia and Eritrea: From Conflict to Cooperation (Lawrenceville: The Red Sea Press), p. 69.
} 
the Boundary and Claims Commissions, the conflict remains unresolved. In fact, since both Commissions have decided for each side on some of the issues presented to them, each side is cherry-picking parts of the awards that are favorable to it and using the same for propaganda to fuel the conflict.

To make progress in all the dimensions of conflict resolution, all stakeholders, and particularly the citizens of the two countries, should be aware that there are multiple tracks to conflict resolution and take matters into their own hands. They should not expect that the governments of the two countries will, for that matter can, resolve every dimension of the conflict one fine morning. Given the current nature and relationship of the political leaderships in the two countries, the approach to the resolution of the conflict should be initiated and steadily nurtured 'bottom-up'. 